\title{
Attitudes of Medical Students towards Suicidal Behavior and Associated Factors
}

\section{Atitudes de Estudantes de Medicina diante do Comportamento Suicida e Fatores Associados}

\author{
Emerson Arcoverde Nunes ${ }^{\mathrm{I}}(\mathbb{D})$ \\ Beatriz Bezerril de Oliveira ${ }^{\mathrm{I}}$ (D) \\ Lucas Bezerril de Lima Galvão ${ }^{1}$
}

\section{KEYWORDS}

- Suicide.

- Suicide Attempted.

- Students.

- Schools Medical.

- Attitude.

Introduction: To evaluate the self-confidence and knowledge of medical students when caring for patients at risk for suicide. Methods: A quantitative cross-sectional study was performed with a sample of 310 medical students from the campus of Universidade Federal do Rio Grande do Norte (UFRN) in Natal, Brazil. Data was collected through the application of the Suicide Behavior Attitude Questionnaire (QuACS, Questionário de Atitudes Frente ao Comportamento Suicida) in association with a sociodemographic questionnaire. The Spearman and Mann-Whitney correlation tests were used to analyze the data. Results: Students closer to the end of the course and those who had practical experience with suicide showed less negative feelings, more sense of professional capacity and less condemnatory attitudes towards suicide. Students in the beginning of the course showed more negative feelings towards suicide. There was no statistically significant influence of gender, having a friend or family member who attempted suicide or past experience of suicidal thoughts on the results. Conclusion: The study strengthens the correlation between the implementation of practical experience and capacitation activities with less negative feelings and increased sense of professional capacity to deal with suicidal behavior. 


\section{PALAVRAS-CHAVE}

- Suicídio.

- Tentativa de Suicídio.

- Estudantes.

- Educação de Graduação em Medicina.

- Atitude.

\section{RESUMO}

Introdução: O objetivo deste estudo foi avaliar a autoconfiança e o conhecimento de estudantes de Medicina para que possam atuar no cuidado de paciente sob risco suicida. Método: Trata-se de estudo transversal quantitativo realizado com amostra de 310 estudantes de Medicina do câmpus da Universidade Federal do Rio Grande do Norte (UFRN), em Natal, no Brasil. Para coleta dos dados dos estudantes, aplicou-se o Questionário de Atitudes Frente ao Comportamento Suicida (QuACS) associado a um questionário sociodemográfico. Para análise dos dados, foram utilizados os testes de correlação de Mann-Whitney e Spearman. Resultados: Os estudantes mais próximos do final do curso e aqueles que já tinham experiência prática com o suicídio demonstraram menos sentimentos negativos, maior sensação de capacidade profissional e atitude menos condenatória com relação ao suicídio. Os alunos do início do curso demonstraram mais sentimentos negativos para com o suicídio. Não houve influência estatisticamente relevante de sexo, possuir amigo ou familiar que já tentou suicídio ou experiência prévia de pensamentos suicidas nos resultados obtidos. Conclusão: $O$ estudo reforça a correlação da implementação de experiências práticas e atividades de capacitação dos alunos com redução de sentimentos negativos e aumento de percepção de capacidade profissional para lidar com o comportamento suicida.

Received on $01 / 19 / 20$

Accepted on $08 / 20 / 20$

\section{INTRODUCTION}

Derived from the Latin, the word 'suicide' has its first historical records in the $17^{\text {th }}$ century, in the work "Religio Medici" by Sir Thomas Browne $e^{1,2}$. Even in antiquity, in the Greco-Roman culture, suicide was a government transgression and, later, with the monotheistic religions, this act started to have theological relevance, being stigmatized as an unjust and unworthy practice. It was only in the nineteenth century, through authors such as Claude-Étienne Bourdin and the Esquirol psychiatric school, that suicide became an object of medical study, and started to be understood as a phenomenon subject to pathological, sociological and philosophical interpretations ${ }^{3,4}$.

Currently, suicidal behavior has shown increasingly higher prevalence rates and has caused important impacts for society and health services, reinforcing the relevance of developing studies on the topic ${ }^{5}$. According to the WHO estimates, around 800,000 people die from suicide each year. Among young people aged 15 to 29 years, these data are even more a matter of concern: considering both genders, suicide is the second leading cause of death in this age range ${ }^{6}$. Worldwide, a person attempts suicide every 03 seconds and every 40 seconds a person commits, in fact, suicide. It is estimated that each death from suicide has an impact on the lives of at least six other people, and that by 2020 there might be a $50 \%$ increase in the annual incidence of suicide deaths ${ }^{7}$.

Suicide is notably multicausal and has as its main risk factors situations such as a previous suicide attempt, low educational or socioeconomic level, abusive use of alcohol or other drugs, diagnosis of chronic or incurable diseases and the presence of mental disorders. This last factor is present in most cases ${ }^{8}$.

Suicide prevention requires the integrated action of a multiprofessional team capable of identifying patients at risk of suicide and adequately managing these cases $^{9,10}$. According to Bertolote, Melo-Santos et al. ${ }^{11}$, the main roles of the health team in relation to suicidal behavior include identifying the risk factors, intervening to remove these factors and choosing the best therapeutic measure to protect the patient.

Studies in this area have suggested that between $40 \%$ and $60 \%$ of people who committed suicide had an appointment with a physician in the month prior to the act, with the majority being treated by general practitioners, not psychiatrists ${ }^{12}$. This statistic is corroborated by the fact that the majority of patients with suicide prediction factors, such as selfharm, are treated in services such as basic health units and emergency rooms, by general practitioners, before a fatal suicide attempt occurs ${ }^{13}$. Nevertheless, the taboo and stigmatization that permeate mental disorders and the suicidal act itself make many people feel unable to talk about the topic or even seek the necessary help ${ }^{14}$. Those who, after overcoming the embarrassment, recognize the problem and decide to seek medical help, present themselves at the time of the consultation with a wide variety of vague pains and complaints, hindering the actual understanding of the health professional about this event and demanding even greater sensitivity to recognize in the patient the warning signs for suicidal behavior ${ }^{12}$.

Recently graduated doctors often work in Primary Health Care (PHC), in settings such as Basic Health Units (BHUs) and Emergency Care Units (ECUs). These scenarios are, in many cases, the gateway for the patient with suicidal ideation or for the person who in fact commits suicide. Therefore, for the professional to have the mastery of this topic during general training is of utmost importance for suicide prevention, given that the management of this condition is not restricted to the limits of psychiatry and psychology ${ }^{15}$.

When doctors have reasonable indications that the patient may commit suicide, they face the dilemma of how to proceed. Therefore, it is necessary to highlight that the understanding of the process that goes from the identification of the patient at risk for suicide to the approach of this patient and the adoption of adequate therapeutic measures is of medical competence. Thus, suicide, due to its high incidence and clinical and social relevance, must also be addressed during undergraduate school, considering that the training of health professionals is characterized as a primary tool to increase their competence in the evaluation and management of suicide risk, as well as in the management towards mental health promotion ${ }^{16}$.

Interventions in the area of health professional training to deal with suicide are increasingly necessary. However, the curricular workload aimed at disciplines in the scope of mental health is generally small and

REVISTA BRASILEIRA DE EDUCAÇÃO MÉDICA

2 44 (4) : e131; 2020 
predominantly theoretical, so that the practical experience is, in most cases, unsatisfactory ${ }^{17}$. Considering the importance of obtaining data on the teaching strategies currently used by the courses, this study aimed to assess the self-confidence and the knowledge of medical students when caring for patients at risk for suicide.

\section{METHODS}

This is a quantitative, cross-sectional study carried out between the years 2018 and 2019 at the Universidade Federal do Rio Grande do Norte (UFRN) campus in the city of Natal, state of Rio Grande do Norte, Brazil.

The inclusion criteria comprised being a medical student attending from the $5^{\text {th }}$ semester on; age $\geq 18$ years and sign the Free and Informed Consent Form (FICF). It was decided not to assess students attending the first four semesters due to the fact that at this phase of the medical course, undergraduate students are less likely to come into contact with situations of suicide during the course activities. During the data collection period, the population eligible for the study comprised 384 students, divided into 49 students from the fifth semester, 46 students from the sixth semester, 52 students from the seventh semester, 49 students from the eighth semester, 50 students from the ninth semester, 49 students from the tenth semester, 42 students from the eleventh semester and 47 students from the twelfth semester. Seventy-four undergraduate students who did not fill out the instruments used during data collection were excluded. Thus, 310 medical students participated in the study.

Data collection took place from March to June 2019, at Hospital Universitário Onofre Lopes, and the places where the interviewees' were approached comprised spaces of interaction and the medical students' classrooms. The students who met the inclusion criteria were invited to answer a sociodemographic questionnaire and the Suicide Behavior Attitude Questionnaire (QUACS) through e-mails, social network messaging apps and direct approach in the classroom. The questionnaires were adapted to the internet using the Google Forms tool. The estimated average time to complete the questionnaires was 10 minutes.

The QUACS, created and validated by Botega et $\mathrm{al}^{18}$ in a study with nursing professionals, consists of 21 statements, followed by a $10-\mathrm{cm}$ visual scale anchored, at its ends, by "completely disagree" and "completely agree". For the present study, the QUACS visual scale was adapted to a numerical scale graduated from 1 to 10 , in which the participants marked the scores that best represented their beliefs. Each item then received an agreement score according to the participant's choice. If the interviewee marked the point that corresponds to 8 on the scale, for example, it was considered that there was an agreement of $80 \%$ with the respective statement.

In the original study, the items were combined into three factors: 1 - Negative feelings towards the patient; 2 - Perception of professional capacity; and 3 - Right to Suicide. Factor 1 includes items 2, 5, 9, 13, 15, 17 and 19 of the questionnaire, with a maximum of 70 points. The higher the score in this factor, the greater the presence of negative feelings. Factor 2 includes items $1,7,10$, and item 12 with a negative value, with a maximum of 40 points. Higher scores in this factor indicate a greater perception of professional capacity to deal with suicidal behavior. Factor 3 includes item 3 with a negative value and items $4,6,16$ and 18 , with a maximum of 50 points. A higher score in this factor indicates a less "moralistic" attitude.

Items $8,11,14,20$ and 21 are not added together as they have no similarity with the constructed factors. Therefore, they can be analyzed separately or excluded from the scale analysis. Cronbach's alpha coefficient was calculated for each factor and the results obtained were $0.7,0.6$ and $0.5^{18}$, respectively.

For the present study, a section was added to the original questionnaire containing sociodemographic data including age, gender, period of graduation and research on subject training, treatment of a suicide case or having a relative who committed suicide.

The data obtained by applying the questionnaires in the Google Forms tool were automatically generated in the Microsoft Excel Program. Subsequently, they were transported from the spreadsheet to the Statistical Package for the Social Sciences (SPSS ${ }^{\circledR}$ ) software for Windows, version 22.0.

For data that did not have a normal distribution, assessed by the Kolmogorov-Smirnov test, Mann-Whitney, Spearman and Kruskal-Wallis non-parametric tests were used with comparison by pairwise for data analysis. The level of significance was set at $\mathrm{p}<0.05$.

The research followed the guidelines and rules of Resolution $\mathrm{N}$. 466/2012, of the Ministry of Health, which regulates the investigation processes involving human beings. The research was started after approval by the Research Ethics Committee of UFRN (approval number 3,084,901). Student enrollment occurred after they agreed to participate, by signing the Free and Informed Consent Form. The confidentiality and anonymity of all information was guaranteed, and the interviewees were free to withdraw their consent at any time without any penalty.

\section{RESULTS}

The sociodemographic and academic data of the study participants are shown in Table 1. The age of the interviewees ranged from 18 to 46 years, with a mean age of 23 years. Most students were between 20 and 25 years old at the time of data collection.

Most students were males (53.9\%), had already treated a patient at risk of suicide (71.6\%), had not taken any training course on the subject (79.4\%) and had a friend or family member who had attempted suicide (58.4\%). In the item that asked about the degree of association between mental illness and suicide, the responses ranged between $0 \%$ and $100 \%$, with an average of $85 \%$. Most respondents (78.3\%) answered with percentages between $75 \%$ and $100 \%$.

Table 2 shows the students' responses in each of the QUACS items. The minimum (0) and maximum (10) scores were obtained for all items. The statement with the lowest mean and highest agreement was question 16 - "Whoever has God in their hearts, won't try to kill themselves", demonstrating a less condemning attitude of the interviewees. Statement 8 - "Generally, those who kill themselves have some mental illness" showed the highest mean, which is in agreement with the question "In your opinion, of the people who committed suicide, how many do you estimate suffered from mental illness? (percentage)" from the first section of the questionnaire.

Table 3 shows the results obtained for each QUACS factor. It seems that Factor 1 had the lowest maximum score according to its reference value, indicating that respondents had less perception of negative feelings related to the suicidal patient. The lowest mean and the lowest minimum score were obtained in Factor 2, highlighting a low perception of professional capacity to deal with suicide. Factor 3 showed the highest mean and the lowest disagreement, demonstrating a less moralistic attitude among the interviewees.

REVISTA BRASILEIRA DE EDUCAÇ̃̃o MÉDICA

3 44(4) : e131; 2020 


\section{Table 1}

Division by number and percentage of sociodemographic and academic variables of the 310 study participants, Natal / RN, 2019.

$\begin{array}{ccc} & \text { Variables } & \text { N, \% } \\ \text { Gender } & & \\ & \text { Female } & 143(46.1 \%) \\ & \text { Male } & 167(53.9 \%)\end{array}$

Ages (years)

$\begin{array}{cc}<20 & 5(1.6 \%) \\ 20-25 & 223(71.9 \%) \\ 25-30 & 68(21.9 \%) \\ >30 & 14(4.5 \%)\end{array}$

Course semester

$\begin{array}{lc}5^{\text {th }} & 41(13.2 \%) \\ 6^{\text {th }} & 41(13.2 \%) \\ 7^{\text {th }} & 45(15.5 \%) \\ 8^{\text {th }} & 40(12.9 \%) \\ 9^{\text {th }} & 41(13.2 \%) \\ 10^{\text {th }} & 36(11.6 \%) \\ 11^{\text {th }} & 31(10 \%) \\ 12^{\text {th }} & 35(11.3 \%)\end{array}$

Have you ever treated a patient at risk of suicide?

$$
\begin{array}{lc}
\text { Yes } & 222(71.6 \%) \\
\text { No } & 88(28.4 \%)
\end{array}
$$

Have you ever taken a training course on suicide?

$$
\begin{array}{ll}
\text { Yes } & 64(20.6 \%) \\
\text { No } & 246(79.4 \%)
\end{array}
$$

Do you have a friend / family member who has attempted suicide?

$$
\begin{array}{ll}
\text { Yes } & 181(58.4 \%) \\
\text { No } & 129(41.6 \%)
\end{array}
$$

In your opinion, of the people who committed suicide, how many do you estimate were suffering from mental illness? (percentage)

$$
0
$$

01 to 25

25 to 50

\begin{tabular}{|c|c|c|c|}
\hline Questions & $\begin{array}{l}\text { Response } \\
\text { range }\end{array}$ & Median & Mean (SD) \\
\hline $\begin{array}{l}\text { I feel capable of helping someone who } \\
\text { tried to kill themselves (Q1) }\end{array}$ & $1-10$ & 6 & $5.65(2.1)$ \\
\hline $\begin{array}{l}\text { Those who are always threatening to kill } \\
\text { themselves, usually do not do it (Q2) }\end{array}$ & $1-10$ & 1 & $1.86(1.79)$ \\
\hline $\begin{array}{l}\text { Despite everything, I think people } \\
\text { have the right to kill themselves (Q3) }\end{array}$ & $1-10$ & 4 & $4.05(2.70)$ \\
\hline $\begin{array}{l}\text { In the presence of suicide, I think: if } \\
\text { someone had talked to them, the person } \\
\text { would have found another way (Q4) }\end{array}$ & $1-10$ & 8 & $7.34(1.99)$ \\
\hline $\begin{array}{l}\text { Deep down inside, I prefer not to } \\
\text { get too involved with patients who } \\
\text { attempted suicide (Q5) }\end{array}$ & $1-10$ & 3 & $3.69(2.55)$ \\
\hline $\begin{array}{l}\text { Life is a gift from God, and only He } \\
\text { can take it away (Q6) }\end{array}$ & $1-10$ & 4 & $4.41(3.19)$ \\
\hline $\begin{array}{l}\text { I feel I am able to perceive when } \\
\text { patients are at risk of killing } \\
\text { themselves (Q7) }\end{array}$ & $1-10$ & 6 & $5.75(2.15)$ \\
\hline $\begin{array}{l}\text { Generally, those who kill themselves } \\
\text { have some mental illness (Q8) }\end{array}$ & $1-10$ & 8 & $8.07(2.07)$ \\
\hline $\begin{array}{l}\text { I am afraid to ask about suicidal } \\
\text { ideation, and end up inducing the } \\
\text { patient to do it (Q9) }\end{array}$ & $1-10$ & 2 & $3.28(2.68)$ \\
\hline $\begin{array}{l}\text { I think I have professional training to deal } \\
\text { with patients at risk of suicide (Q10) }\end{array}$ & $1-10$ & 5 & $4.52(2.93)$ \\
\hline $\begin{array}{l}\text { I think you have to be a brave person } \\
\text { to kill yourself (Q11) }\end{array}$ & $1-10$ & 5 & $5.48(3.12)$ \\
\hline $\begin{array}{l}\text { I feel insecure to take care of patients } \\
\text { at risk of suicide (Q12) }\end{array}$ & $1-10$ & 7 & $6.60(2.52)$ \\
\hline $\begin{array}{l}\text { Sometimes it makes me angry, } \\
\text { because so there are many people } \\
\text { who want to live ... and that patient } \\
\text { wants to die (Q13) }\end{array}$ & $1-10$ & 1 & $1.92(1.86)$ \\
\hline $\begin{array}{l}\text { If I suggest a referral to the psychiatrist } \\
\text { for a patient who talked about killing } \\
\text { themselves, I think this will be well } \\
\text { accepted by the psychiatrist (Q14) }\end{array}$ & $1-10$ & 8 & $7.55(2.42)$ \\
\hline $\begin{array}{l}\text { We feel powerless in the presence } \\
\text { of a person who wants to kill } \\
\text { themselves (Q15) }\end{array}$ & $1-10$ & 7 & $6.24(2.57)$ \\
\hline $\begin{array}{l}\text { Those who have God in their heart, } \\
\text { will not try to kill themselves (Q16) }\end{array}$ & $1-10$ & 1 & $1.65(1.52)$ \\
\hline $\begin{array}{l}\text { In the case of patients who are } \\
\text { suffering a lot due to a physical } \\
\text { illness, I find the idea of suicide more } \\
\text { acceptable (Q17) }\end{array}$ & $1-10$ & 4 & $4.20(2.78)$ \\
\hline $\begin{array}{l}\text { When a person talks about ending } \\
\text { their life, I try to get the idea out of } \\
\text { their head (Q18) }\end{array}$ & $1-10$ & 7 & 7.15 (2.29) \\
\hline
\end{tabular}

51 to 75

$41(13.2 \%)$

75 to 99

$119(38.3 \%$

100

$124(40 \%)$

Source: Elaborated by the authors.

Table 2

Response range, median, mean and standard deviation of the scores obtained by the study participants in the items of the QuACS questionnaire, Natal/RN, 2019.

Continue... 


\begin{tabular}{|c|c|c|c|}
\hline \multicolumn{4}{|c|}{$\begin{array}{c}\text { Table } 2 \\
\text { Continuation }\end{array}$} \\
\hline Questions & $\begin{array}{c}\text { Response } \\
\text { range }\end{array}$ & Median & Mean (SD) \\
\hline $\begin{array}{l}\text { Anyone who wants to kill themselves, } \\
\text { does not keep "trying" to kill } \\
\text { themselves (Q19) }\end{array}$ & $1-10$ & 1 & $1.71(1.54)$ \\
\hline $\begin{array}{l}\text { An inpatient will not kill } \\
\text { themselves without having a strong } \\
\text { reason for it (Q20) }\end{array}$ & $1-10$ & 3 & $3.32(2.57)$ \\
\hline $\begin{array}{l}\text { I have been through situations that } \\
\text { made me think about suicide (Q21) }\end{array}$ & $1-10$ & 3 & $4.45(3.50)$ \\
\hline
\end{tabular}

Source: Elaborated by the authors.

\begin{tabular}{|c|c|c|c|c|}
\hline \multicolumn{5}{|c|}{$\begin{array}{l}\text { Table } 3 \\
\text { Response range, maximum score, mean, standard deviation and } \\
\text { median of the results obtained by the research participants in the } \\
\text { factors studied by the QuACS questionnaire, Natal / RN, } 2019 \text {. }\end{array}$} \\
\hline Factors & $\begin{array}{l}\text { Response } \\
\text { range }\end{array}$ & $\begin{array}{l}\text { Maximum } \\
\text { score }\end{array}$ & $\begin{array}{l}\text { Mean } \\
(\mathrm{SD})\end{array}$ & Median \\
\hline $\begin{array}{l}\text { Factor } 01 \text { - Negative feelings } \\
\text { towards the suicidal patient }\end{array}$ & $7-49$ & 70 & $\begin{array}{l}22.91 \\
(8.20)\end{array}$ & 22 \\
\hline $\begin{array}{l}\text { Factor } 02 \text { - Perception of } \\
\text { professional competence }\end{array}$ & 3-39 & 40 & $\begin{array}{l}19.32 \\
(7.44)\end{array}$ & 20 \\
\hline Factor 03 - Right to suicide & $9-48$ & 50 & $\begin{array}{l}26.50 \\
(6.78)\end{array}$ & 26 \\
\hline
\end{tabular}

Source: Elaborated by the authors.
Table 4 shows the association between each of the interviewed academic periods and the mean score obtained in the QUACS. It is possible to observe less negative feelings and a greater perception of professional capacity in relation to the patient at suicidal risk in the $12^{\text {th }}$ semester class. Lower perceptions of professional capacity are observed in the $5^{\text {th }}$ and $6^{\text {th }}$ semesters. The greatest perception of negative feelings related to the suicidal patient is observed in the $5^{\text {th }}$ semester, which has not yet had contact with any discipline related to Psychiatry or Mental Health. The class with the highest mean in Factor 3 - "Right to suicide" was the one at the $10^{\text {th }}$ semester of medical school.

Table 5 shows the comparisons between the means obtained in the QuACS questionnaire according to the sociodemographic and educational variables. It is observed that interviewees who had already treated a patient at risk of suicide or had already taken a training course on the subject had higher scores in factors 1 and 2, demonstrating that such students had less negative feelings about the patient at risk of suicide and considered they had a greater professional capacity to deal with the topic.

In Factor 3, the only variable that showed statistical relevance was the one related to having treated a patient at risk of suicide, demonstrating the importance of medical practice. There was no significant difference between gender or having family members/friends who had attempted suicide in relation to the score obtained in the factors.

The application of the Kruskal-Wallis non-parametric test in the analysis of the score obtained in the factors regarding the semester the interviewees were attending at the time of data collection showed that there were significant differences in factors 1 and $2(\mathrm{p}=0.00)$ in relation to the semester the interviewees were attending. This test led to the performance of multiple comparisons by pairwise; however, multiple comparisons were not performed for Factor 3, as the entire test did not show significant differences between the samples.

Comparison of the results of mean, standard deviation (SD) and median values in each factor analyzed in the QuACS questionnaire, according to
the semesters (S) of the medical course at UFRN, Natal / RN, 2019.

Source: Elaborated by the authors. 


\begin{tabular}{|c|c|c|c|c|c|c|}
\hline Comparison & $\begin{array}{r}\text { ndard deviati } \\
\text { anc }\end{array}$ & $\begin{array}{l}\text { alue in ez } \\
\text { al variabl }\end{array}$ & $\begin{array}{l}\text { ble } 5 \\
\text { nalyzed in th } \\
\text { search partic }\end{array}$ & $\begin{array}{l}\text { questionı } \\
\mathrm{al} / \mathrm{RN} \text {, }\end{array}$ & ding to the & ographic \\
\hline \multirow[t]{2}{*}{ Variable } & Factor 1 & & Factor 2 & & Factor 3 & \\
\hline & Mean (SD) & p-value & Mean (SD) & p-value & Mean (SD) & p-value \\
\hline Gender & & 0.26 & & 0.02 & & 0.9 \\
\hline Female & $23.48(8.41)$ & & $18.34(6.82)$ & & $26.44(6.65)$ & \\
\hline Male & $22.42(8.01)$ & & $20.16(7.85)$ & & $26.56(6.90)$ & \\
\hline
\end{tabular}

Have you ever treated a patient at risk of suicide?

0.00

0.00

$21.41(6.86)$

$14.06(6.15)$

$\begin{array}{ll}\text { Yes } & 22.00(8.43) \\ \text { No } & 25.20(7.15)\end{array}$

Have you ever taken a training course on suicide?

0.00

$23.22(7.02)$
$18.33(7.24)$
0.06

$27.95(6.27)$

$26.13(6.87)$

Do you have a friend / family member who has attempted suicide?

$\begin{array}{ll}\text { Yes } & 23.23(8.01) \\ \text { No } & 22.47(8.48)\end{array}$

$19.94(7.06)$

$26.32(6.59)$

$18.44(7.88)$

$26.76(7.05)$

Source: Elaborated by the authors.

Pairwise comparisons were then made for Factor 1. There was no difference when comparing the twelfth semester with the three initial semesters $(p=0.00)$, the eleventh semester with the fifth $(p=0.00)$ and the seventh semester $(\mathrm{p}=0.01)$ and the tenth, ninth and eighth semesters also had lower scores in the item "negative feelings" than the fifth semester (respectively: $\mathrm{p}=0.00, \mathrm{p}=0.03$ and $\mathrm{p}=0.05$ ).

The ninth, tenth, eleventh and twelfth semesters had significant differences when compared to the group that had not yet had any contact with psychiatry in the medical course. In addition, the twelfth semester class was the one that showed the best results in comparison with the other semesters.

Factor 2 was also analyzed by pairwise comparison, which showed differences between the classes of the twelfth, eleventh, tenth, ninth and eighth semesters as to the classes of the fifth and sixth semesters ( $p=$ 0.00 for all comparisons). In addition, classes in the tenth, eleventh and twelfth semesters also showed statistical differences when compared to the seventh semester $(\mathrm{p}=0.00)$. The three initial classes of the study were those that obtained the lowest average in Factor 2, indicating less sense of ability to deal with a patient at risk of suicide.

\section{DISCUSSION}

This study aimed to assess the knowledge and attitudes of UFRN medical students about suicide and to analyze the sociodemographic and educational characteristics that influenced these aspects.

There was no statistically significant difference between the female or male genders and the QUACS scores, and in each of the 21 statements of the questionnaire, there was an indication of agreement and full disagreement, demonstrating that the opinions and attitudes related to each of the questions related to suicide and its factors were diverse. This finding is consistent with studies carried out with nursing professionals ${ }^{19}$.

According to WHO data, the main identifiable risk factor for suicide is the concomitant presence of mental disorders ${ }^{14}$. In the present study, the respondents also obtained high association rates (85\%). However, it is noteworthy that two of the interviewees denied any association between these variables.

Contrary to what was expected, having a friend/family member who has attempted suicide was not related to significant changes in any of the factors, demonstrating that only contact from professional experiences and adequate training were able to minimize the prejudice and improve the skills in the management of these patients. This assertion is reinforced by the fact that the interviewees who scored higher in item 21 "I have been through situations that made me think about suicide", demonstrating that they had gone through some psychological suffering that made them think about committing suicide, showed better capacity to deal with patients who also experienced this suffering.

It is important to note that $47(15 \%)$ of the interviewees obtained maximum agreement with the item in question 21 , stating that they had experienced situations that made them think about committing suicide. This finding is important, as it indicates the need for a constant assessment of the mental health of medical students, since studies indicate that the suicide rate among physicians is three to five-fold higher than that of the general population ${ }^{20}$. It is therefore suggested that further studies be carried out to fully assess the risk of suicide in this population and the implementation of support interventions for these students.

It was observed that students who are at the end of the course are less likely to have negative feelings about suicide, feel more empowered to deal with the problem and also have a greater perception of one's rights

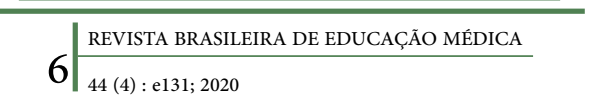


about suicide, demonstrating that a higher educational level related to the practice environment of the last two years of medical school internship contributes to reduce the stigmatization of the suicidal patient and can contribute to a more qualified care to these patients.

The interviewees who had already had some practical experience treating a patient at risk of self-extermination also had better scores in the three analyzed factors. Having taken a training course was also a positive influence on factors 1 and 2, demonstrating that greater contact with this topic positively influences the perception of professional capacity and makes condemnatory and negative attitudes towards suicidal patients less common.

Students from $5^{\text {th }}$ and $6^{\text {th }}$ semesters had a high score for the factor 'negative feelings towards the suicidal patient'. These attitudes are more often associated with the lack of knowledge about the topic and can negatively influence the quality of the provided care. It should be noted that students in the $5^{\text {th }}$ semester have not yet experienced any discipline related to mental health in the UFRN medical course, and students in the $6^{\text {th }}$ semester were, at the period of data collection, attending the discipline of Psychiatry.

Considering the sample totality and the proportion of the maximum values attributed to each factor, students from the $5^{\text {th }}$ to the $12^{\text {th }}$ semesters of UFRN had low scores in Factor 1 (Negative feelings towards the suicidal patient), with an also reduced maximum score (49). However, the respondents also obtained low means in Factor 2 (Perception of professional capacity), demonstrating the need for continuing education on the topic, as they did not feel safe enough to treat patients at risk of suicide.

The $5^{\text {th }}$ semester students obtained a mean of 13.66 in Factor 2. Considering that at this point in the medical course these students were still starting the first clinical discipline and had not yet attended any discipline that directly involved psychiatric subjects, the mean was considered as consistent with studies carried out with Brazilian university students from diverse courses and with no training on the subject, who obtained a mean of 15.5 in this same factor ${ }^{21}$.

It was possible to verify a progressive increase in this factor according to the advancing of the medical course semesters. The $12^{\text {th }}$ semester showed an increase of more than $85 \%$ in this factor when compared to the $5^{\text {th }}$ semester class, demonstrating the positivity of the qualification actions carried out through lectures and the contact with patients in clinical disciplines, reinforcing the need for more curricular actions within the scope of the students' training to treat this specific population.

A study carried out with medical students from another institution in our country ${ }^{22}$, also found results that indicated the observation that the group of students already included in the course's cynical cycle had higher scores when compared to students in the preclinical cycle, pointing to an indication that students at more advanced semesters exhibited more positive attitudes towards suicide when compared to students starting medical school. Although this study is different from the present one, the students did not had significant differences in factors 1 and 2, showing a significant difference only in the final score of the QuACS scale ${ }^{22}$. Moreover, the analyses were carried out in two groups (pre- and postclinical), while in our study the analyses were made by comparing the semesters individually, which may have provided a better assessment regarding the possible interventions to be considered, based on our observations, with proposals for training or other didactic activities related to suicide prevention.
It is worth mentioning that the mean score of all students assessed in this study regarding factor 02 (19.32) was still lower than the maximum possible mean score for this factor (40 points). This finding should be considered important, since professional insecurity to deal with suicide may be associated with insufficient knowledge and, consequently, result in ineffective and deficient care, being harmful to the user at risk for suicide ${ }^{23}$.

As a limitation of this study, its low scope stands out, since it was carried out at a single public university in Rio Grande do Norte, making it necessary to expand the sample to other universities and other regions of the country to increase the external validity of the findings. Moreover, the adaptation of QuACS to the virtual environment, due to the difficulty of interviewing students who were attending the internship in person, may have generated responses in duplicate, leading to information bias. Such biases were minimized by tracking duplicate responses in the study.

Despite the three months of collection, only 310 of the 384 eligible students participated in the study $(80.72 \%)$, thus generating a non-response bias. Moreover, the QuACS questionnaire, although already validated, was initially used in studies with nursing professionals, whereas in this study the target audience that was interviewed comprised undergraduate medical students.

\section{CONCLUSION}

Suicide is a disorder of increasing relevance, and patients at risk for this behavior are often treated by recently-graduated doctors. In this study, personal experiences involving suicide, such as having a friend/ family member who has attempted suicide or having had suicidal ideas, did not show a correlation with the assessed outcomes. The exposure during professional training activities, however, showed a correlation with prejudice minimization and the improvement of skills in managing suicide. Although these factors reinforce the importance of using effective strategies for teaching how to deal with suicide even during undergraduate school, there was a low perception of professional capacity among the assessed students. Therefore, further studies are necessary, aiming to diagnose problems and suggest improvements in the curriculum, to allow the training of physicians with skills compatible with the increasing relevance of suicidal behavior.

\section{REFERENCES}

1. Barraclough B, Shepherd D. A necessary neologism: the origin and uses of suicide. Suicide Life Threat Behav. 1994;24(2):113-26.

2. André W. Sobre o conceito de suicídio. Estação Literária. 2018;20:154-74.

3. Ribeiro DM. Suicídio: critérios científicos e legais de análise. Jus Navigandi. 2004;9. Available at https://jus.com.br/artigos/5670.

4. Reis AH, Bezerra JMM, Reis PMS. O suicídio na visão do século XIX e na contemporaneidade - desafios aos paradigmas médico e psicológico. Revista Científica do UniRios. 2020.2383-97.

5. Macchiaverni J. Elaboração de um instrumento para registro de atendimento psicológico a tentativas de suicídio. Santa Catarina: Universidade Federal de Santa Catarina; 2012.

6. World Health Organization. Suicide in the world: global health estimates. Geneva: WHO; 2019.

7. Conselho Federal de Medicina, Associação Brasileira de Psiquiatria. Suicídio: informando para prevenir. Brasília: Conselho Federal de Medicina, Associação Brasileira de Psiquiatria; 2014 [Avaliar ajuste].

REVISTA BRASILEIRA DE EDUCAÇÃO MÉDICA

$744(4):$ el31; 2020 
8. Crump C, Sundquist K, Sundquist J, Winkleby MA. Sociodemographic, psychiatric and somatic risk factors for suicide: a Swedish national cohort study. Psychol Med. 2014;44(2):279-89.

9. Botega NJ, Werlang BSG, Cais CFS, Macedo MMK. Prevenção do comportamento suicida. Psico. 2006;37:213-20.

10. Müller S de A, Pereira G, Zanon RB. Estratégias de prevenção e pósvenção do suicídio: estudo com profissionais de um Centro de Atenção Psicossocial. Rev. Psicol IMED. 2017;9(2):6-23.

11. Bertolote JM, Mello-Santos C, Botega NJ. Detecting suicide risk at psychiatric emergency services. Braz J Psychiatry. 2010;32(Suppl 2):S87-95.

12. Organização Mundial da Saúde. Prevenção do suicídio: um manual para profissionais de saúde em atenção primária. Genebra: OMS; 2000.

13. Vidal CE, Gontijo EC, Lima LA. Attempted suicide: prognostic factors and estimated excess mortality. Cad Saude Publica. 2013;29(1):175-87.

14. World Health Organization. Preventing suicide: a global imperative. Geneva: WHO; 2014.

15. Meleiro AMAS. Atendimento de pacientes com comportamento suicida na prática médica. Rev. bras. med. 2013;70:22-7.

16. Kotowski A, Roye C. Development of instructional competencies for assessing and managing suicide risk for baccalaureate nursing education: a modified Delphi study. Issues Ment Health Nurs. 2017;38(3):233-42.

17. Pereira AA, Costa ANd, Megale RF. Mental health for primary care family doctors: a contribution to improve educational programs. Rev Bras Educ Med. 2012;36(2):269-79.

18. Botega NJ, Reginato DG, Silva SV da, Cais CF, Rapeli CB, Mauro ML, et al. Nursing personnel attitudes towards suicide: the development of a measure scale. Braz J Psychiatry. 2005;27(4):315-8.
19. Magrini DF. Atitudes dos profissionais de enfermagem que atuam em emergências diante do comportamento suicida e fatores associados. Masters thesis. Ribeirão Preto: Universidade de São Paulo; 2016.

20. Kamski L, Frank E, Wenzel V. Suicide in medical students: case series. Anaesthesist. 2012;61(11):984-8.

21. Kirchner LF, Queluz FNFR. Conhecimento e atitudes de universitários acerca do suicídio: influências sociodemográficas e acadêmicas. Brazilian Journal of Health Review. 2019;2(4):3120-30.

22. Magalhães CA, Neves DMM, Brito LMDM, Leite BBC, Pimenta MMF, Vidal CEL. Atitudes de estudantes de medicina em relação ao suicídio. Rev Bras Educ Med. 2014;38(4):470-6. doi: 10.1590/S010055022014000400008 .

23. Silva LLT. Atitudes e percepções de estudantes e professores de enfermagem frente ao suicídio de adolescentes. Doctorate thesis. Belo Horizonte: Universidade Federal de Minas Gerais; 2014.

\section{AUTHORS' CONTRIBUTION}

All authors collaborated equally for the study project, writing and revision of the manuscript.

\section{CONFLICTS OF INTEREST}

The authors declare no conflicts of interest.

\section{ADDRESS FOR CORRESPONDENCE}

Emerson Arcoverde Nunes. Hospital Universitário Onofre Lopes, Avenida Nilo Peçanha, 620, Natal, RN, Brasil. CEP: 59012-300.

E-mail: emerson_arcoverde@yahoo.com.br 